\title{
ISOLATED FETAL LIVER CALCIFICATIONS: PRENATAL MANAGEMENT
}

\author{
Doga Fatma OCAL ${ }^{1}$, Yasemin CEKMEZ ${ }^{1}$, Burak Mehmet OZKAN ${ }^{1}$, Enis OZKAYA ${ }^{1}$, Gulnihal REYHAN ${ }^{1}$, \\ Aydan Asyalı BIRI ${ }^{2}$, Tuncay KUCUKOZKAN ${ }^{1}$
}

1 Dr. Sami Ulus Gynecology and Obstetrics Teaching and Researching Hospital, Ankara

2 Department of Obstetrics and Gynecology, Gazi University Faculty of Medicine, Ankara

\begin{abstract}
SUMMARY
Objective: The aim of this study was to determine the incidence and clinical significance of isolated fetal liver calcifications. Material and methods: Between 2008 -2012 we were performed 19200 detailed fetal ultrasonography screening between 18-28 weeks of gestation and cases with isolated fetal liver calcifications were enrolled in the study. A detailed fetal ultrasound imaging for associated abnormalities, the serological status for maternal TORCH (toxoplasma, rubella, cytomegalovirus, herpesvirus), syphilis and parvovirus B-19 was determined. Doppler ultrasound was used to detect a possible flow in the echogenic lesions. Amniocentesis was offered in all cases. All neonates were examined and followed up after birth.

Results: We were detected 17 women with isolated fetal liver calcifications. All of the calcifications were isolated, solitary and parenchymal. None of the fetuses was associated with other organs abnormalities or intrauterine infections. Amniocentesis results of 14 women who accepted this procedure were normal.
\end{abstract}

Conclusion: If fetal liver calcifications are isolated, the prognosis will be good.

Key words: liver calcifications, isolated, fetal, ultrasound.

Journal of Turkish Society of Obstetrics and Gynecology, (J Turk Soc Obstet Gynecol), 2014; Vol: 11, Issue: 1, Pages: 10-3

\section{IZOLE FETAL KARACİ̆ER KALSIFIKASYONLARI: PRENATAL YÖNETIM}

\section{ÖZET}

Amaç: Bu çalışmanın amacı izole fetal karaciğer kalsifikasyonlarının insidansını ve klinik önemini saptamaktır. Gereç ve yöntemler: 2005-2012 yılları arasında 18-28 gestasyonel haftalar arası 19200 gebeye detaylı ultrasonografi yapıldı ve izole fetal karaciğer kalsifikasyonu saptananlar çalışmaya alındı. Eşlik eden anomaliler için detaylı fetal ultrasonografik görüntüleme ve maternal TORCH (toxoplasma, rubella, sitomegalovirus, herpesvirus), sifiliz ve parvovirus B-19 açısından serolojik inceleme yapıldı. Ekojenik lezyonlar olası bir akım varlı̆̆ açısından Doppler ultrasonografi ile değerlendirildi. Tüm olgulara amniyosentez önerildi. Tüm yenidoğanlar doğumdan sonra değerlendirildi ve izleme alındl. Bulgular: İzole fetal karaciğer kalsifikasyonu olan 17 olgu saptandı. Tüm kalsifikasyonlar tek, izole ve parankimaldi. Fetuslarda eşlik eden intrauterin enfeksiyon ya da diğer organ anomalilerine ait bulgu saptanmadl. Amniyosentez yaptırmayı kabul eden 14 olgunun sonuçları normaldi.

Sonuç: Saptanan fetal karaciğer kalsifikasyonları izole ise yüksek olasılıkla iyi seyirli olacağı düşünülebilir.

Anahtar kelimeler: karaciğer kalsifikasyonu, izole, fetal, ultrasonografi

Türk Jinekoloji ve Obstetrik Derneği Dergisi, (J Turk Soc Obstet Gynecol), 2014; Cilt: 11, Sayl: 1, Sayfa: 10-3

Address for Correspondence: Dr. Doğa Fatma Öcal. Dr. Sami Ulus Kadın Hastalıkları Doğum ve Eğitim Araştırma Hastanesi, Ankara Phone: + 90 (533) 8109879

e-mail: eadoga@yahoo.com

Received: 02 June 2013, revised: 16 October 2013, accepted: 17 October 2013, online publication 20 October 2013 


\section{INTRODUCTION}

Liver calcification seems as a hyperechogenic area in the paranchyme or surface of liver with ultrasonographic imaging ${ }^{(1)}$. It can be isolated finding or in association with other abnormalities. Although isoleted fetal liver calcification has been seen relatively common the clinical significance and management of it has not been fully established $(2,3)$. The aim of this study is to discuss clinical management and peritanal outcomes of 17 patients who were evaluated with isolated fetal liver calcification.

\section{MATERIAL AND METHODS}

This study was performed at Gazi University, Faculty of Medicine, Department of Obstetrics and Gynecology between 2005-2010 and subsequently performed at Dr. Sami Ulus Women Health and Research Hospital between 2010-2012. In the seven-year period we were performed 19200 routine detailed fetal scans (of theese 15200 were from Gazi University) between 18-28 weeks of gestation and 17 cases with isolated fetal liver calcifications were enrolled in the study. Demographic properties of cases such as age, gravity, parity, number of menstrual regulation (MR), abortion and living child were recorded (Table I). Ultrasound images were obtained using Philips HD $11 \mathrm{XE}$ and GE logic S9 ultrasound devices. All sonographic examinations were performed by two experienced sonographists that one of them was perinatologist while the other one was radiologist. All neonates were followed after birth at least for 12 months. In each case a series of initial and follow-up obstetric ultrasound imaging were obtained (four-weeks interval for the two trimesters and two weeks for the last trimester). Localization and number of the hyperechogenicity were recorded. Patients were screened for other associated abnormalities by detailed ultrasonography. Doppler ultrasound was used to evaluate vascularity of echogenic lesions. In all cases the serological status for toxoplasmosis, rubella, cytomegalovirus, herpesvirus (TORCH), syphilis, parvovirus B19 was determined. Imulite 2000 Siemens commercial kits for serological assessment of toxoplasma, rubella and CMV, Diapro for herpes (manuel, micro ELISA), Novatech for parvovirus B19 and Omega for syphilis (VDRL) were used. Amniocentesis was proposed to cases detected fetal liver calcification for chromosomal analysis and determination of intrauterine infections. After the birth, newborns physical, serological examinations for TORCH, syphilis and parvovirus were performed. Antenatal diagnostics of isolated fetal liver calcifications were confirmed by postpartum sonographic screening performed by radiologist. Neonates were followed-up by three-months period sonographic examinations until 12. months after the birth.

\begin{tabular}{lcc}
\hline & Median & $\begin{array}{c}\text { Standart } \\
\text { deviation }\end{array}$ \\
\hline Age & 25 & 5.1 \\
Gravity & 2 & 1.2 \\
Parity & 1 & 1.1 \\
MR & 0 & 0 \\
Abortion & 0 & 0.56 \\
Living child & 1 & 0.89 \\
\hline
\end{tabular}

\section{Results}

$17(0.09 \%)$ cases of isolated fetal liver calcifications were detected among 19200 women. Thus our incidence was $1 / 1123$. All of the calcifications were isolated, parenchymal and solitare (Figure 1 and 2). The earliest case we detected fetal liver calcification was at the 18 th week of gestation and the latest was at the 26 th week of gestation. Color Doppler flow imaging was demonstreted no vascularization in the hepatic lesions of each case. Serologic markers of TORCH, syphilis and parvovius B-19 which performed from mothers blood were negative in all cases. Amniocentesis was performed on the 14 of 17 fetuses to determine chromosomal abnormalities and intrauterine infections. The results were normal for each fetus. There was no associated obstetric morbidity during the follow-up the cases. The size and number of the fetal liver calcifications did not change during the pregnancy. All of the foetuses were delivered at term and the physical, serological, abdominal and cranial ultrasonographic examinations were normal except liver calcification for each neonate. All neonates were followed after birth at least for 12 months and no additional pathology was detected. 

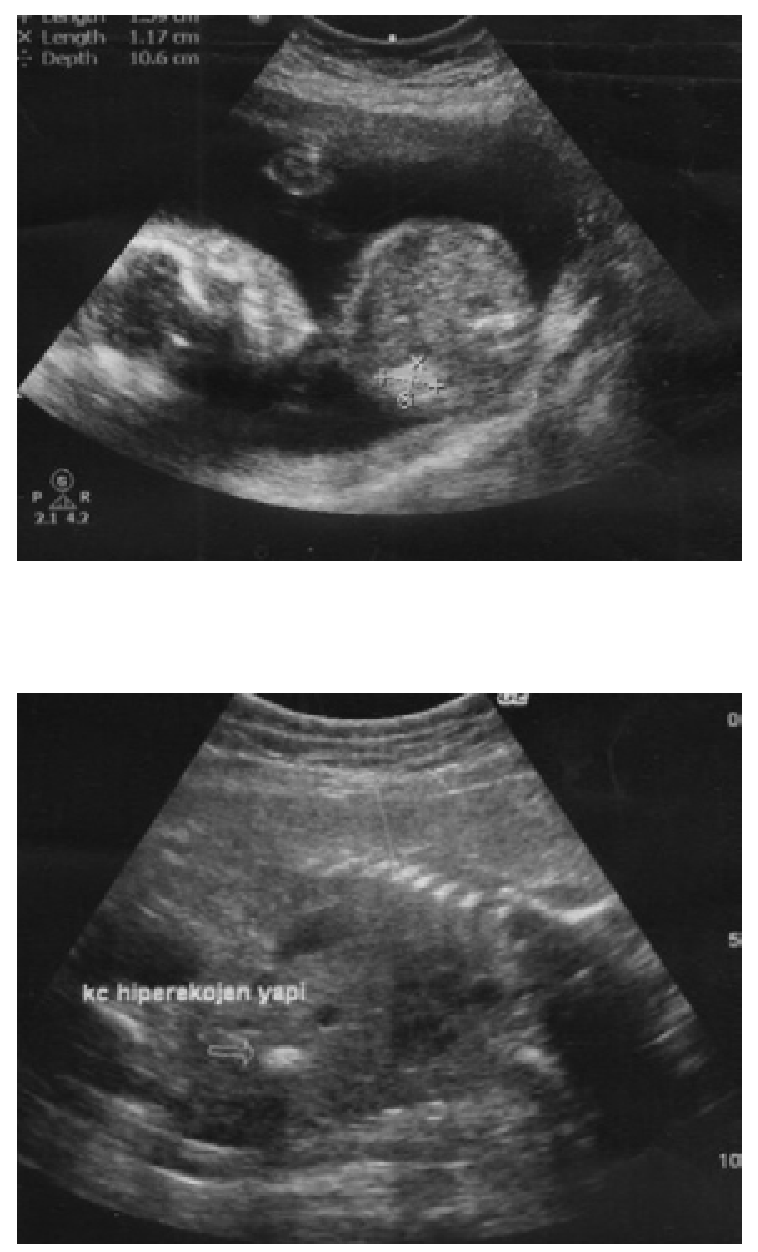

DICUSSION

Fetal liver calcifications were previously detected from spontaneous abortions and newborn autopsies ${ }^{(4)}$. Nowadays owing to advances in ultrasonography resolution, we can detect calcifications at earlier weeks of gestation(5). The incidence of isolated fetal liver calcifications is undetermined while the incidence of whole fetal liver calcifications was estimated as 5.7$10 / 10000^{(1-14)}$. It may be due to the fact that our hospital is a referral center so we were found the incidence higher than other publications. The location and the number of calcifications may be important for etiology and they are classified as parenchymal, peritoneal and vascular calcifications ${ }^{(12)}$. However, Simchen et al. showed that there were no differences between parenchymal and surface liver calcifications regarding the cause and outcome. They were therefore divided fetal liver calcifications into two groups; isolated and non-isolated ${ }^{(2)}$. Parenchymal calcifications were detected especially at pregnancies which complicated with intrauterine infections, primary or methastatic liver tumours, gall-bladder stones and vasculare thrombosis $(2,6,7,13)$. Chromosomale anomalies also might cause fetal liver calcifications ${ }^{(2,8)}$. If one of the above conditions were caused fetal liver calcifications then we would detect findings of other affected organs as hepatomegaly, calcifications of spleen, serologic findinsg, cardiac findings such as myocarditis, hydrops fetalis seconder to cardiac failure, intrauterine growth retardation (iugr), placental abnormalities and fetal intracranial patologies. Fetal liver calcifications may show different clinical course depending on whether there was any associated anomaly and number of calcifications. Because of this when a hyperechogenicity was detected in the hepatic area, detailed ultrasound screening should be done to determine the number of detected fetal liver hyperechogenicity and whether accompanying anomalies. Subsequently infection markers should be examined in order to investigate the possible causes. Amniosentesis may be recommended in all patients with fetal liver calcifications but it has been reported in the literature that the probability of chromosomal anomalies in patients without concomitant abnormalities is very low. Therefore amniosentesis should be performed only in patients with associated anomalies ${ }^{(2)}$. In current study although concomitant patology was detected in none of the cases, we did amniosentesis in 14 of 17 cases. In 3 cases the parents did not allow such an examination so we did not do.

In conclusion, the significance of fetal liver calcifications has to be assessed in combination with other clinical and pathological parameters, including location and number of the lesions, and abnormalities of placenta, umbilical cord, and fetal malformations ${ }^{(14)}$. The common opinion of all studies including current study is that if the fetal liver calcification is isolated, with no associated morphologic abnormalities, abnormal caryotypes or intrauterine infection, the prognosis will be good.

\section{REFERENCES}

1. Rypens F, Avni EF, Abehsera MM, Donner C, Vermeylen DE, Struyven JL. Areas of increased echogenicity in the fetal abdomen: diagnosis and significance. Radiographics 1995; 15(6):1329-44. 
2. Simchen MJ, Toi A, Bona M, Alkazaleh F, Ryan G, Chitayat D. Fetal hepatic calcifications: prenatal diagnosis and outcome. Am J Obstet Gynecol 2002;187(6):1617-22.

3. Achiron R, Seidman DS, Atek A, Malinger G, Lipitz S, Mashiach S, et al. Prenatal ultrasonographic diagnosis of fetal hepatic hyperechogenicities: Ultrasound Obstet Gynecol 1996; 7(4): 251-5.

4. Hawass ND, el Badawi MG, Fatani JA, al-Meshar İ A, Makanjoula D, Edress YB. Foetal hepatic calcification. Pediatr Radiol 1990;20(7):528-35.

5. Özyapı AG, Kars B, Karşıdağ AYK, Büyükbayrak EE, Ünal O, Turan MC. İzole fetal karaciğer kalsifikasyonu. J Turk Soc Obstet Gynecol 2010;7(Ek-1):50-4.

6. Chow Kc, Lee CC, Lin Ty, Shen WC, Wang JH, Peng CT, et al. Congenital enterovirus 71 infection: a case study with virology and immunohistochemistry. Clin Infect Dis 2000; 31(12):509-12.

7. McNamara A, Levine D. Intraabdominal fetal echogenic masses: a practical guide to diagnosis and management. Radiographics 2005;25(3):633-45.
8. Koopman E, Wladimiroff JW. Fetal intrahepatic hyperechogenic foci: prenatal ultrasound diagnosis and outcome. Prenat Diagn 1998;18(4):339-42.

9. Bronshtein M, Blazer S. Prenatal diagnosis of liver calcifications. Obstet Gynecol 1995;86(5):739-43.

10. Stein B, Bromley B, Michlewitz H, Miller WA, Benacerraf BR. Fetal liver calcifications: sonographic appearance and postnatal outcome. Radiology 1995;197(2):489-92.

11. Dündar Ö, Müngen E, Tütüncü L, Muhcu M, Yergök YZ. Fetal intrahepatik kalsifikasyon: Olgu sunumu. Perinatoloji Dergisi 2006; $14 ; 154-8$

12. Carroll SG, Maxwell DJ. The significance of echogenic areas in the fetal abdomen. Ultrasound Obstet Gynecol 1996; 7(4):293-8.

13. Fleischer AC, Manning FA, Jeanty P, Romero R. Sonography in obstetrics and gynecology: principles and practice. 6 th edition Appleton\&Lange.2001

14. Kidron D, Sharony R. Fetal liver calcifications: an autopsy study. Virchows Arch 2012;460(4):399-406. 